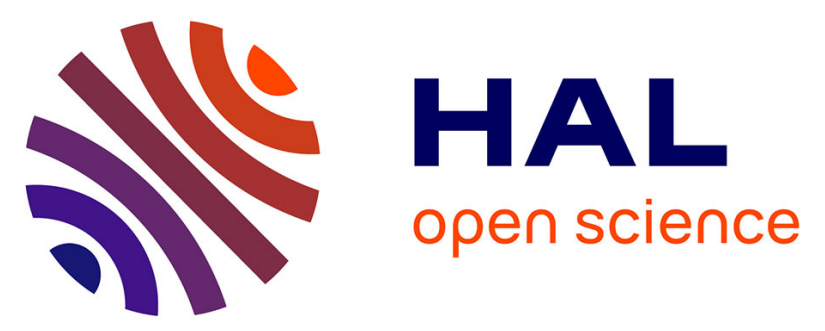

\title{
Purification of pentoses from hemicellulosic hydrolysates with sulfuric acid recovery by using electrodialysis
} Julien Lemaire, Claire-Line Blanc, Fanny Duval, Marc-André Théoleyre, Dominique Pareau

\section{To cite this version:}

Julien Lemaire, Claire-Line Blanc, Fanny Duval, Marc-André Théoleyre, Dominique Pareau. Purification of pentoses from hemicellulosic hydrolysates with sulfuric acid recovery by using electrodialysis. Separation and Purification Technology, 2016, 166, pp.181-186. 10.1016/j.seppur.2016.04.030 . hal01310364

\section{HAL Id: hal-01310364 \\ https://hal.science/hal-01310364}

Submitted on 9 Nov 2016

HAL is a multi-disciplinary open access archive for the deposit and dissemination of scientific research documents, whether they are published or not. The documents may come from teaching and research institutions in France or abroad, or from public or private research centers.
L'archive ouverte pluridisciplinaire HAL, est destinée au dépôt et à la diffusion de documents scientifiques de niveau recherche, publiés ou non, émanant des établissements d'enseignement et de recherche français ou étrangers, des laboratoires publics ou privés. 
1 Purification of pentoses from hemicellulosic hydrolysates with sulfuric acid recovery by using electrodialysis

3 Julien Lemaire*, Claire-Line Blanc, FannyDuval, Marc-André Theoleyre, Dominique Pareau

LGPM, CentraleSupélec, Université Paris-Saclay, SFR Condorcet FR CNRS 3417, Centre Européen de Biotechnologie et de Bioéconomie (CEBB), chemin des Sohettes 51110 Pomacle, France

\section{Abstract}

The valorization of lignocellulosic biomass as a renewable carbon source is growing in chemical industries, particularly in the agro-industrial sector. Many chemicals compounds and bio-based intermediates can be produced but their production needs to be more costcompetitive. The valorization of pentoses in hemicellulosic hydrolysates, obtained by using dilute sulfuric acid, is of growing interest. However, current downstream processes which involve a partial or complete neutralization of the acid are not satisfactory for economic and environmental reasons.

This work presents a method of purification of pentoses with sulfuric acid recovery which reduces water and chemicals consumptions. The results obtained at the laboratory scale with wheat bran hydrolysates are very promising. The process is based on the combination of ultrafiltration, conventional electrodialysis and ion-exchange. A special organic UF membrane (Alpha Laval - UFX10pHt), resistant to acidic conditions, removed totallymacromolecules which can damage the electrodialysis unit by precipitation, with good mean permeate flow rate $\left(24 \mathrm{~L} \cdot \mathrm{h}^{-1} \cdot \mathrm{m}^{-2}\right.$ till VCF $\left.=4.4\right)$. Then, conventional electrodialysis was performed to recover most of sulfuric acid (>80\%) without losing sugars $(<1 \%)$ with an acceptable faradic yield (70\%). The specific energy consumption of the electrodialysis stack was interesting (0.6 kWh per kgof $\mathrm{H}_{2} \mathrm{SO}_{4}$ recovered and $4.2 \mathrm{kWh}$ per $\mathrm{m}^{3}$ of hydrolysate). Finally, the complete demineralization (conductivity $<10 \mu \mathrm{S} . \mathrm{cm}^{-1}$ ) and discoloration $(420 \mathrm{~nm}$ 
25 absorbance $<0.01$ ) of the pentoses solution was obtained by ion-exchange with about a 10-

26 fold increase of resins capacity (20 BV) compared to conventional processes with a 27 neutralization step (2 BV).

28 Keywords:electrodialysis;pentoses; purification;acid recycling; green chemistry.

\section{Highlights}

- A purification process of pentoses from hemicellulosic hydrolysates was developed.

31 - Ultrafiltration, electrodialysis and ion exchange were combined.

- Sulfuric acid can be recycled for the hydrolysis step of lignocellulosic biomass.

- Less water and reagents were required to demineralize the hydrolysate.

- Process eco-efficient and economical compared to conventional methods.

35

${ }^{*}$ Corresponding author.

37 Present address: CentraleSupélec, CEBB, chemin des Sohettes 51110 Pomacle, France.

Tel.: +33(0) 326464985 . 


\section{Introduction}

Lignocellulosic biomass is an attractive renewable carbon source for agro-industries, such as food or forestry industries. Actually, it generates large amounts of coproducts (wheat straw and bran, sugar beet pulp, wood waste ...) which are often poorly valued [1]. Many chemicals compounds and bio-based intermediates can be produced from these lignocellulosic residues such as sugars, paper pulp, surfactants, polymers or bioethanol. In the frame of sustainable development, the green chemistry and the valorization of these coproducts to produce bio-based molecules is of growing interest $[2,3]$.

Lignocellulosic biomass is mainly composed of cellulose (40 to $50 \%$ ), lignins (10 to $35 \%_{w}$ ) and hemicellulose (20 to $45 \%_{w}$ ) which is a copolymer of pentoses and hexoses.

Generally, the hydrolysis of lignocellulosic biomass is very difficult because of its recalcitrant structure (low porosity, crystallinity, high molecular weights). This treatment aims at extracting cellulose fibers by solubilizing lignins and hemicellulose. Three main processes are used at industrial scale: Kraft process using alkaline solution like caustic soda in paper industry, "Organo-solv" processes using organic solvents such as acetone, ethanol or acetic acid, and hydrolysis with dilute inorganic acids [4,5]. However, others methods using steam, hot water or a combination of enzymes can also be used. After treatment, a complex mixture of pentoses, hexoses, lignins and mineral salts must be separated to value them.

The present article deals with the valorization of pentoses in hydrolysates obtained by using dilute inorganic acids, more particularly sulfuric acid. Indeed, pentoses have found many applications recently (xylitol, bio-based building blocks, surfactants and biopolymers). Currently, the industrial methods begin with a partial or complete neutralization of the inorganic acid in order to precipitate lignins, proteins and eventually metal residues by using caustic soda or lime. Then pentoses are purified by ion-exchange [6-8], adsorption, chromatography or crystallization [9-11]. This process is not satisfactory for economic and environmental reasons. Indeed, large amount of base is required, resulting in greatly increased amount of salts, needing more water and chemical reagents to separate them. 
Moreover it generates large volume of effluent and the acid catalyst cannot be recycled to the hydrolysis step.

For a decade, the use of electrodialysis (ED) has been growing because of its efficiency to separate ions without consuming chemical reagents or water. ED is an electrochemical separation technique which uses an electric potential as driving force to move ions through selective ion-exchange membranes in order to separate them from others molecules present in solution $[12,13]$. ED has been applied to demineralize aqueous solutions, desalinate seawater and purify wastewater [14-16]. Besides, ED has been widely used in bioprocesses to separate organic acids (lactic, citric, acetic, succinic oxalic) and amino acids [17-20]. Within the framework of pentoses purification in hemicellulosic hydrolysates, ED proved to be an alternative promising demineralization method but partial or complete neutralization was still required $[2,21,22]$ so as to eliminate macromolecules (lignins and proteins) which could precipitate during ED. Indeed, ED membranes are quite expensive and are dramatically damaged by clogging.

The objective of this study was to investigate the feasibility of sulfuric acid recovery from lignocellulosic hydrolysates in the frame of pentoses valorization. The present process combines ultrafiltration (UF), conventional electrodialysis and ion-exchange (IE) and does not need neutralization step, that is a significant advantage in terms of economy and environment. First, the influence of the nature (mineral or organic) and the cut-off of UF membranes on the elimination of macromolecules precipitating during $E D$, due to a $\mathrm{pH}$ increase, were studied. Then the ED performances were investigated for acid recovery and demineralization. Finally, a polishing treatment by IE was performed to get a solution of sugars with very low conductivity $\left(<10 \mu \mathrm{S} . \mathrm{cm}^{-1}\right)$ and totally discolored. This work proposes an eco-efficient process to purify pentoses from hemicellulosic hydrolysates.

\section{Materials and methods}

\subsection{Hemicellulosic hydrolysate}


The lignocellulosic hydrolysate was produced from wheat bran milled then mixed with a dilute sulfuric acid solution $\left(\approx 10 \mathrm{~g} \cdot \mathrm{L}^{-1}\right)$. Its main properties are given in table 1 . Before performing ultrafiltration, centrifugation was required to remove suspended matter, whose

97 content is about $1.5 \mathrm{~g} \cdot \mathrm{L}^{-1}$.

\begin{tabular}{|c|c|c|}
\hline Dry weight & 8.2 & $\% w$ \\
\hline $\mathrm{pH}$ & 1.1 & - \\
\hline Conductivity & 34.5 & $\mathrm{mS} . \mathrm{cm}^{-1}$ \\
\hline Absorbance at $420 \mathrm{~nm}$ & 2.2 & - \\
\hline $\mathrm{H}_{2} \mathrm{SO}_{4}$ & 8.7 & $g \cdot L^{-1}$ \\
\hline Glucose & 12.8 & \\
\hline Xylose & 21.3 & g. $L^{-1}$ \\
\hline Arabinose & 10.6 & \\
\hline Sodium & 1.9 & \\
\hline Potassium & 4.7 & \\
\hline Ammonium & 14.8 & \\
\hline Magnesium & 2.8 & \\
\hline Calcium & 4.6 & \\
\hline Total cations & 28.8 & $\mathrm{mEq} \cdot \mathrm{L}^{-1}$ \\
\hline Chlorure & 2.0 & \\
\hline Nitrate & 0.9 & \\
\hline Phosphate & 24.3 & \\
\hline Sulfate & 175.2 & \\
\hline Total anions & 202.4 & \\
\hline
\end{tabular}

100 Our pilot device can perform cross-flow filtration through different kinds of membrane with 101 various cut-offs for microfiltration (MF), ultrafiltration (UF), nanofiltration (NF) or reverse 102 osmosis (RO). Two ceramic tubular membranes in series (TAMI) and up to 40 organic flat 103 sheet membranes (Alpha-Laval), composed of polysulfone and polypropylene, in a plate104 and-frame module can be used (table 2). 


\begin{tabular}{ccc} 
& UF ceramic & UF organic \\
\hline Surface $\left(\mathrm{cm}^{2}\right)$ & 50 & 180 \\
Length $(\mathrm{cm})$ & 25 & - \\
Diameter $(\mathrm{mm})$ & 6 & 100 \\
\hline $\mathrm{pH}$ & 0 to 14 & 1 to 13 \\
Pressure $($ bar $)$ & 1 to 15 & 1 to 10 \\
Temperature $\left({ }^{\circ} \mathrm{C}\right)$ & $<120$ & $<75$ \\
& $8($ TAMI $)$ & $10($ UFX10pHt) \\
Cut-off $(\mathrm{kD})$ & $15($ TAMI) & $20(\mathrm{GR61PP})$ \\
& & $50(\mathrm{GR} 51 \mathrm{PP})$ \\
\hline
\end{tabular}

The centrifugal pump could reach 60 bars and the cross-flow rates were generally comprised between 5 and 100 L. $\mathrm{h}^{-1} \cdot \mathrm{m}^{-2}$ with operating conditions recommended by suppliers.

108 The temperature was controlled between 20 to $80^{\circ} \mathrm{C}$ by using a heat exchanger combined 109 with a thermostat. The volume of the UF tank containing the retentate was about $8 \mathrm{~L}$.

\subsection{Conventional electrodialysis unit}

Our conventional ED unit (Eurodialndustrie) is composed of one stack with 10 unit cells, a voltage generator, three tanks (capacity $=2 \mathrm{~L}$ ) containing the brine, the product and the electrolyte and three pumps ensuring the flow of each solution through the corresponding compartment (table 3). Conventional ED was used to transfer acids and salts from the

115 product to the brine. The conductivity, $\mathrm{pH}$, acid concentration, sugar concentration and ion 116 concentration of the brine and the product were monitored as well as the current intensity.

117 This unit was optimized for demineralization by the manufacturer. Operating conditions 118 (flow rates, current, voltage, electrolyte and initial brine composition) were fixed according to 119 manufacturer's recommendations. Conventional ED is generally performed with a constant 120 tension so the limiting current density is not a constant and decreases during 121 demineralization. Tension (12 V) was determined to work always under the limiting current 122 density so as to optimize energy consumption and faradic yield.

\begin{tabular}{ll}
\hline Stack & 10 unit cells \\
\hline
\end{tabular}




\begin{tabular}{cc}
\hline Total active surface & $0,2 \mathrm{~m}^{2}$ \\
Initial brine & $5 \mathrm{mS} . \mathrm{cm}^{-1} \mathrm{H}_{2} \mathrm{SO}_{4}$ \\
Electrolyte & $20 \mathrm{mS} . \mathrm{cm}^{-1} \mathrm{NaCl}$ \\
Voltage & $12 \mathrm{~V}$ \\
Product flowrate & $180 \mathrm{~L} \cdot \mathrm{h}^{-1}$ \\
Brine flowrate & $180 \mathrm{~L} \cdot \mathrm{h}^{-1}$ \\
Electrolyte flowrate & $200 \mathrm{~L} \cdot \mathrm{h}^{-1}$ \\
Current density max & $45 \mathrm{~mA} \cdot \mathrm{cm}^{-2}$ \\
\hline
\end{tabular}

124

125

126

127

128

129

130

131

132

133

134 135

\subsection{Ion-exchange system}

The polishing treatment by ion-exchange (IE) was performed at laboratory scale in two vertical double jacket glass columns operating in series, filled respectively with $350 \mathrm{~mL}$ of a strong anionic resin (LEWATIT S7468) in the $\mathrm{OH}$ form and a strong cationic resin (LEWATIT S2528) in the $\mathrm{H}$ form. Their inner diameter was $25 \mathrm{~mm}$ and the bed height $70 \mathrm{~cm}$. A thermostat was used to maintain the water jacket at $40^{\circ} \mathrm{C}$ while the product was injected at room temperature at $4 \mathrm{BV} \cdot \mathrm{h}^{-1}$. BV is a common unit used to express volumes or flow rates as a function of the bed volume.

The flow rate was controlled by a peristaltic pump and the mobile phase flew from the top to the bottom of glass columns. An automatic sampling system was used at the output in order to monitor $\mathrm{pH}$, conductivity, acid concentration, sugar concentration and ion concentration of the product.

The regeneration procedure for the anionic and cationic resins begins with the elution of 2 $\mathrm{BV}$ at $2 \mathrm{BV} \cdot \mathrm{h}^{-1}$ of respectively $1 \mathrm{M} \mathrm{NaOH}$ solution and $1 \mathrm{M} \mathrm{HCl}$ solution in separated columns. Then, columns are connected and resins are rinsed with reverse osmosis water till the conductivity of output solution remains constant (close to input conductivity).

\subsection{Analytical methods}

Conductivity and $\mathrm{pH}$ were measured with a 340i conductimeter/pH-meter from WTW. Dry matter was estimated by refractometry using a brixmeter (RFM732 Bellingham+Stanley). Sample color was estimated by measuring absorbance at $420 \mathrm{~nm}$ with a spectrophotometer 
144 (UV-1800, Shimadzu). $\mathrm{H}_{2} \mathrm{SO}_{4}$ concentration was evaluated by titration with $0.1 \mathrm{M} \mathrm{NaOH}$ from

145 the volume required to reach $\mathrm{pH} 4.0$, so as to consider only strong acidity.

146 Sugars were analysed with an HPLC system (Ultimate 3000, Dionex) equipped with a 147 pump, an auto sampler and a RI-101 refractometer at $35^{\circ} \mathrm{C}$ (Shodex). The analytical column 148 was an Aminex HPX-87H (Biorad) along with a matching guard column (Micro-Guard 149 cartridge, Biorad). The column temperature was maintained at $45^{\circ} \mathrm{C}$ with a column oven 150 controller. The mobile phase was $2 \mathrm{mM} \mathrm{H}_{2} \mathrm{SO}_{4}$ in milli-Q water (Direct 8, Millipore), degassed 151 by an on-line vacuum degasser. The flowrate was set to $0.5 \mathrm{~mL}^{\mathrm{min}}{ }^{-1}$ and the injection 152 volume to $10 \mu \mathrm{L}$.

Anions and cations were analysed with an HPIC system (ICS-5000+, Thermo Scientific Dionex) equipped with two pumps, an auto sampler, two eluent generators, a column oven controller set to $35^{\circ} \mathrm{C}$ and two suppressors. Detection is performed by conductivity. For anion analysis, the column was an lonpack AS11HC 2x250 mm along with a matching guard column (AG11HC 2x50 mm). The eluent generator produced a $30 \mathrm{mM} \mathrm{KOH}$ solution for the mobile phase. The flowrate was set to $0.3 \mathrm{~mL} \cdot \mathrm{min}^{-1}$, the suppressor to $23 \mathrm{~mA}$ and the injection volume to $2.5 \mu \mathrm{L}$. For cation analysis, the column was an lonpack CS16 $3 \times 250 \mathrm{~mm}$

160 along with a matching guard column (CG16 3x50 mm). The eluent generator produced a 30 $161 \mathrm{mM}$ methanesulfonic acid solution for the mobile phase. The flowrate was set to $0.36 \mathrm{~mL} \cdot \mathrm{min}^{-}$ 162 ${ }^{1}$, the suppressor to $32 \mathrm{~mA}$ and the injection volume to $10 \mu \mathrm{L}$.

\section{Results and discussion}

\subsection{Removal of macromolecules by ultrafiltration}

Macromolecules like lignins or proteins must be removed from the hydrolysate before performing ED because they will damage the electrodialysis stack by precipitation due to $\mathrm{pH}$ increase during the treatment. UF with ceramic membranes and organic membranes (2 flat sheets, total surface $=0.036 \mathrm{~m} 2$ ) was investigated to remove macromolecules, without $\mathrm{pH}$ adjustment so without reagents consumption in contrast with existing processes. 
170

Temperature was set to $40^{\circ} \mathrm{C}$ and transmembrane pressure to 6 bar. So as to evaluate their performance, the amount of precipitates in hydrolysate samples before and after UF was measured at different $\mathrm{pH}$, which was adjusted with soda (table 4). Precipitates were filtered on $0.22 \mu \mathrm{m}$ PTFE filter then their dry weight was measured by a moisture analyzer (Sartorius MA150).

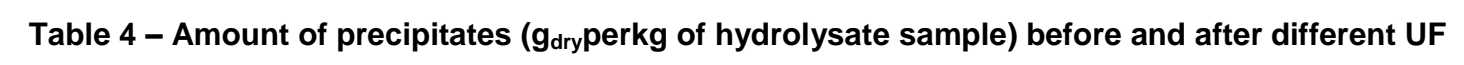

\begin{tabular}{ccccc}
\hline $\mathrm{pH}$ & Before UF & Ceramic 15 kD & Ceramic 8 kD & Organic 10/20/50 kD \\
\hline 1.1 & 0 & 0 & 0 & 0 \\
2 & 0.22 & 0.19 & 0.19 & 0 \\
2.5 & 0.42 & 0.42 & 0.38 & 0 \\
3 & 0.62 & 0.60 & 0.53 & 0 \\
6 & 0.80 & 0.81 & 0.71 & 0 \\
\hline
\end{tabular}

Only the organic membranes (10 to $50 \mathrm{kD}$ ) were efficient to retain totally macromolecules which precipitate with increasing $\mathrm{pH}$, although some of them had a higher cut-off than the ceramic membranes. These results highlighted the great influence of the membrane nature on macromolecules retention. Liu et al. [23] also found that permeate flux and rejection rate (for lignin removal) were not only determined by pore size of inorganic membrane, but also by membrane charge and hydrophobicity. The influence of membrane nature for the treatment of hemicellulosic hydrolysates is not well detailed in literature. Besides, the membrane geometry (tubular or flat sheets in a plate-and-frame module) can play also a significant role. Indeed, it affects the membrane fouling, concentration polarization or cake formation which impact the permeate flux and retention rates.

Initial permeate fluxes were respectively equal to 25,28 and $94 \mathrm{~L}_{\mathrm{h}} \mathrm{h}^{-1} \cdot \mathrm{m}^{-2}$ with 10,20 and $50 \mathrm{kD}$ organic membranes. A more detailed experiment was performed with the $10 \mathrm{kD}$ organic membrane to evaluate UF performances till a volumetric concentration factor (VCF) equal to 4.4 (table 5). Indeed, generally the permeate flux decrease progressively owing to 
191 membrane fouling. The dead volume of the UF device was about $1 \mathrm{~L}$, so the feed was initially

192 slightly diluted with the rinsing water retained inside.

\begin{tabular}{cccc}
\hline & Feed & Retentate & Permeate \\
Volume (L) & 8.0 & 1.8 & 6.2 \\
Dry weight $\left(\%_{\mathrm{w}}\right)$ & 7.3 & 11.6 & 7.0 \\
$\mathrm{pH}$ & 1.3 & 1.3 & 1.3 \\
Conductivity $\left(\mathrm{mS} . \mathrm{cm}^{-1}\right)$ & 31.5 & 30.2 & 34.5 \\
Absorbance at $420 \mathrm{~nm}$ & 2.1 & 6.5 & 0.5 \\
\hline
\end{tabular}

194

195

196

197

\subsection{Acid recovery and demineralization by conventional electrodialysis}

Conventional ED was used to extract most of the sulfuric acid present in the lignocellulosic hydrolysate which is partially demineralized in the same time. Two hydrolysate samples, previously ultrafiltered with $10 \mathrm{kD}$ organic membranes, were treated successively with the same brine. The brine was reused for the second treatment in order to increase its $\mathrm{H}_{2} \mathrm{SO}_{4}$ concentration and made it reusable in hydrolysis step of lignocellulosic biomass. These experiments aimed at proving the feasibility of acid recovery in the frame of pentoses purification in lignocellulosic hydrolysates.

The $1^{\text {st }}$ ED was performed with $2 L$ of hydrolysate and $2 L$ of fresh brine. The dead volume of the ED unit is about $0.5 \mathrm{~L}$. So the feed was again slightly diluted with the rinsing water retained inside. Figure 1 presents the variation of conductivity, $\mathrm{pH}$, current intensity and faradic yield over time. 

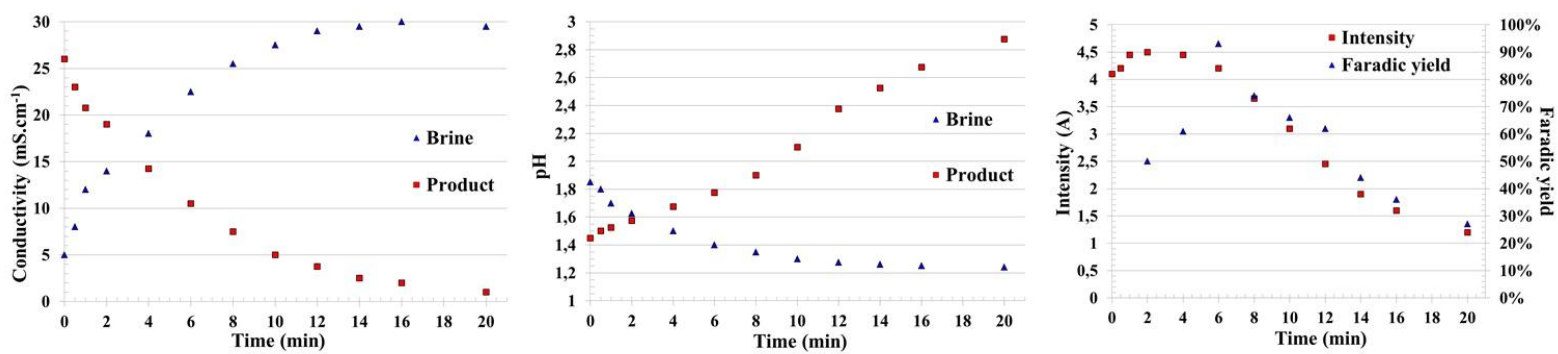

Figure 1 - Monitoring of conductivity and $\mathrm{pH}$ of brine and product and variation of current intensity and faradic yield during the $1^{\text {st }}$ ED with fresh brine

The product was almost totally demineralized (conductivity $<1 \mathrm{mS} . \mathrm{cm}^{-1}$ ) after $20 \mathrm{~min}$ of 214 treatment, meanwhile its $\mathrm{pH}$ reached 2.9. The faradic yield decreased below $50 \%$ after 14 215 min and was equal to $62 \%$ on average. This low faradic yield was expected because of high 216 mobility of $\mathrm{H}^{+}$that are difficult to keep in brine compartment. According to table 6, about $90 \%$ 217 of sulfuric acid was transferred into the brine, meanwhile sugars remained almost completely 218 in the product (>99\%). $\mathrm{H}_{2} \mathrm{SO}_{4}$ concentration of the brine reached $5.9 \mathrm{~g} \cdot \mathrm{L}^{-1}$, which was not 219 enough to be used for hydrolysis step. This is the reason why this brine was reused for the $2202^{\text {nd }} E D$.

Table 6 - Analysis of brine and product after the $1^{\text {st }}$ ED with fresh brine and the $2^{\text {nd }}$ ED with brine reuse

\begin{tabular}{ccccccccc}
\cline { 3 - 8 } & & $\begin{array}{c}\text { Volume } \\
(\mathrm{L})\end{array}$ & $\mathrm{pH}$ & $\begin{array}{c}\text { Conductivity } \\
\left(\mathrm{mS}_{\mathrm{cm}} \mathrm{cm}^{-1}\right)\end{array}$ & $\begin{array}{c}\mathrm{H}_{2} \mathrm{SO}_{4} \\
\left(\mathrm{~g} . \mathrm{L}^{-1}\right)\end{array}$ & $\begin{array}{c}\text { Glucose } \\
\left(\mathrm{g} . \mathrm{L}^{-1}\right)\end{array}$ & $\begin{array}{c}\text { Xylose } \\
\left(\mathrm{g} . \mathrm{L}^{-1}\right)\end{array}$ & $\begin{array}{c}\text { Arabinose } \\
\left(\mathrm{g} . \mathrm{L}^{-1}\right)\end{array}$ \\
\hline $\begin{array}{c}\text { Before } \\
\mathrm{ED}\end{array}$ & Product & - & 1.4 & 27.2 & 6.0 & 7.5 & 15.5 & 7.3 \\
\hline $\begin{array}{c}1^{\text {st }} \mathrm{ED} \\
\text { with fresh } \\
\text { brine }\end{array}$ & Product & 2 & 3.1 & 0.5 & 0.8 & 7.5 & 15.4 & 7.3 \\
\hline $\begin{array}{c}2^{\text {nd }} \mathrm{ED} \\
\text { wine }\end{array}$ & Brine & 2 & 1.3 & 27.1 & 5.9 & $<0.2$ & $<0.2$ & $<0.2$ \\
$\begin{array}{c}\text { reuse } \\
\text { reune }\end{array}$ & Brine & 1.2 & 1.0 & 60.0 & 14.2 & $<0.2$ & 0.4 & $<0.2$ \\
\hline
\end{tabular}

The $2^{\text {nd }} E D$ was performed with $2.2 \mathrm{~L}$ of hydrolysate and $1.2 \mathrm{~L}$ of the brine recovered after 223 the $1^{\text {st }}$ ED so as to get a $\mathrm{H}_{2} \mathrm{SO}_{4}$ concentration up to $15 \mathrm{~g} \cdot \mathrm{L}^{-1}$. As previously, the product was 224 almost totally demineralized after $20 \mathrm{~min}$ and the same $\mathrm{pH}$, conductivity and current intensity profiles were observed over time. About $80 \%$ of sulfuric acid was recovered in the reused 
226 brine, meanwhile most of sugars (> 99\%) remained in the product (table 6). The $\mathrm{H}_{2} \mathrm{SO}_{4}$ 227 concentration of the brine reached $14.2 \mathrm{~g} \cdot \mathrm{L}^{-1}$ and its $\mathrm{pH}$ was equal to 1 . So, this time, the 228 brine could be recycled to the hydrolysis step.

A last ED experiment was performed with $2 L$ of hydrolysate and $2 L$ of fresh brine in order to study the transfer rate of acids and different salts during the treatment. Indeed, if acids are extracted faster than other salts (mainly sodium, potassium, ammonium, magnesium and calcium salts), ED could be performed advantageously in two steps: a first one with a reduced operation time to recover most of acids in a first brine, a second one to extract most of other salts in a second brine. This method could be used to limit the accumulation of other salts in the brine intended to be recycled for hydrolysis step. Figure 2 presents the recovery rates of acids and other salts in the brine over time. ED was performed during only 12 min so as to recover most of acidsand keep the faradic yield above $50 \%$. In this case, the faradic yield remained acceptable (70\%) and the specific energy consumption of the electrodialysis stack was quite interesting ( $0.6 \mathrm{kWh}$ per $\mathrm{kg} \mathrm{of} \mathrm{H}_{2} \mathrm{SO}_{4}$ recovered and 4.2 $\mathrm{kWh}$ per $\mathrm{m}^{3}$ of hydrolysate). The recovery rates of major cations and anions are detailed.
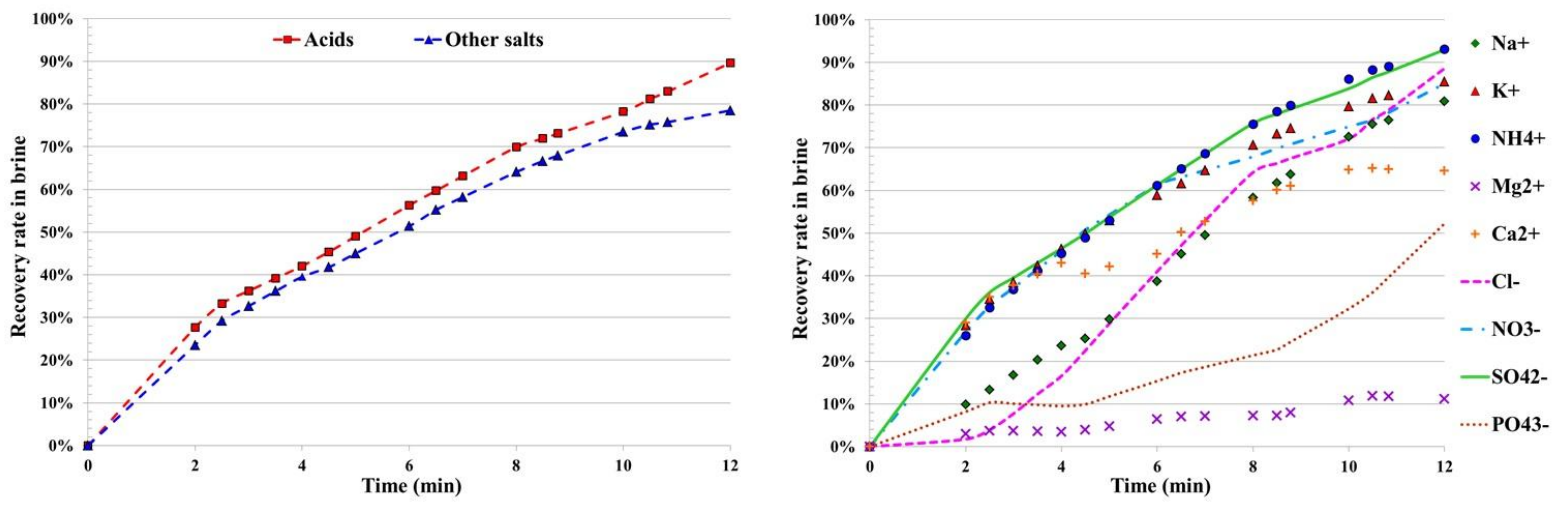

Figure 2 - Recovery rate of acids and other salts over time during ED with fresh brine

We observed that acids are transferred slightly faster than other salts but not enough to recover most of them without most of other salts. Consequently the implementation of ED in two steps did not appear advantageous for this kind of hydrolysates, containing mainly ammonium, potassium and calcium salts (table 1). Indeed, these cations were extracted as 
247 fast as acids (mainly sulfuric acid). Nevertheless, it could be advantageous for hydrolysates 248 containing almost sodium or magnesium salts since these cations were recovered quite 249 slower than acids (figure 2). The accumulation of ammonium, potassium and calcium salts in 250 the brine recycled for hydrolysis step has to be watched and might require a periodic purge. 251 As the concentration of cations is quite low compared to acid, we expect that their 252 accumulation in brine will be relatively slow. Thus, if a periodic purge is sometimes 253 necessary, it must be only occasional. Currently, in a pilot scale study, the brine reused for 254 hydrolysis was as efficient as fresh sulfuric acid to treat wheat bran. Indeed, hydrolysates 255 produced with reused sulfuric acid had exactly the same content except for salts. The brine 256 which has to be purged could be considered as a waste or might be valorized if it is relevant 257 economically. For example, it could be treated by chromatography with ion-exchange resins 258 to separate acids from salts.

Finally an additional polishing treatment by IE was required to remove salts completely 260 and economically. Indeed, the faradic yield of ED dropped below $30 \%$ after 20 min when the 261 product conductivity was around $1 \mathrm{mS} . \mathrm{cm}^{-1}$.

\subsection{Polishing treatment by ion-exchange}

The product of ED was treated by IE to remove totally the salts and organic impurities 264 which could be retained in the polymer matrix of resins. The strong anionic and cationic 265 resins have respectively a total capacity of 1.0 and 1.75 eq. $\mathrm{L}_{\text {bed }}^{-1}$. Figure 3 presents the 266 product $\mathrm{pH}$ and conductivity as a function of the volume injected. The same treatment was 267 applied to a sample of hydrolysate neutralized with lime as in conventional processes, in order to highlight the advantages of the present process. 


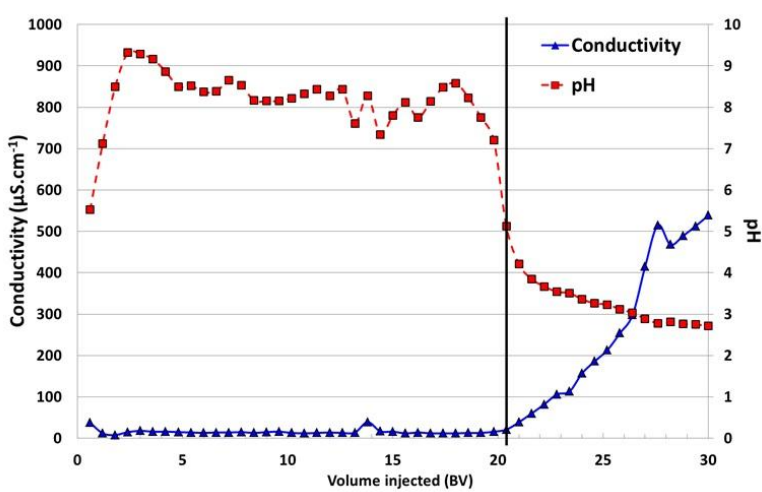

Figure 3 - Monitoring of the product $\mathrm{pH}$ and conductivity during demineralization by ion-exchange

$20 \mathrm{BV}$ of hydrolysate treated by ED (conductivity $=1.5 \mathrm{mS} . \mathrm{cm}^{-1}$, salts ca. 20 meq. $\mathrm{L}^{-1}$ ) were completely demineralized (conductivity $<10 \mu \mathrm{S} . \mathrm{cm}^{-1}$ ) before saturation of one of the resins, while only $2 \mathrm{BV}$ of hydrolysate neutralized with lime were treated before saturation. Consequently, the present process greatly reduces water and chemical reagents needs, 275 particularly in the resin regeneration and rinsing steps. Besides, the product was totally 276 discolored (absorbance at $420 \mathrm{~nm}<0.01$ ). Finally, the separation of sugars (glucose, xylose 277 and arabinose) can be achieved classically by continuous chromatography (SMB, SSMB or 278 ISMB methods) or crystallization [9-11].

\section{Conclusion}

The developed process is a promising pathway to reduce energy, water and chemicals consumptions, the cost of pentoses purification and the impacts on environment. Currently, the improvement of downstream processing is a key factor to make biorefinery productions more cost-competitive. The results at the laboratory scale proved that pentoses can be purified eco-efficiently from dilute sulfuric acid hydrolysates of wheat bran, with acid recovery.

This new process is based on the combination of ultrafiltration, conventional electrodialysis and ion-exchange. First, the ultrafiltration step with organic membranes can efficiently remove macromolecules which can damage irreversibly the electrodialysis unit by precipitation. Then, most of the sulfuric acid can be recovered effectively by conventional 
electrodialysis. Most of other salts (mainly ammonium, potassium and calcium salts) are coextracted and their accumulation in the recycled brine has to be watched and might require anoccasional purge. Nevertheless, the recycling of sulfuric acid keeps very interesting economically. Finally, the polishing treatment by IE can fully demineralize and discolor the solution of pentoses whose purification can be achieved classically by continuous chromatography or crystallization.

In comparison with traditional processes that involve hydrolysate neutralization with lime or caustic soda, the present method gets several economic and environmental advantages:

a) recovery of most of sulfuric acid that can be reused for hydrolysis step, b) saving of lime or 299 caustic soda that would be required for neutralization, c) consecutive decrease of salts to be 300 removed, resulting in energy, water and chemicals savings for demineralization, d) reduction of effluents and other wastes.

Further investigations will be done at a larger scale in order to study the process 303 feasibility and reliability, meanwhile to optimize its performances.

304

305 306 307 308

\section{Acknowledgements}

The authors would like to thank Fondation Paris-Reims, Région Champagne-Ardenne, Département de la Marne and Reims Métropole for their financial support and ARD for the hydrolysate supply.

\section{References}

[1] L. Jacquemin, R. Zeitoun, C. Sablayrolles, P.-Y.Pontalier, L. Rigal, Evaluation of the technical and environmental performances of extraction and purification processes of arabinoxylans from wheat straw and bran, Process Biochem. $47 \quad$ (2012) 373-380. doi:10.1016/j.procbio.2011.10.025.

[2] K.-K. Cheng, B.-Y.Cai, J.-A. Zhang, H.-Z.Ling, Y.-J.Zhou, J.-P.Ge, et al., Sugarcane bagasse hemicellulose hydrolysate for ethanol production by acid recovery process, Biochem. Eng. J. 38 (2008) 105-109. doi:10.1016/j.bej.2007.07.012. 
[3] H.-J. Huang, S. Ramaswamy, U.W. Tschirner, B.V. Ramarao, A review of separation technologies in current and future biorefineries, Sep. Purif. Technol. 62 (2008) 1-21. doi:10.1016/j.seppur.2007.12.011.

[4] M. FitzPatrick, P. Champagne, M.F. Cunningham, R.A. Whitney, A biorefinery processing perspective: treatment of lignocellulosic materials for the production of value-added products, Bioresour. Technol. 101 (2010) 8915-8922. doi:10.1016/j.biortech.2010.06.125.

[5] N. Sarkar, S.K. Ghosh, S. Bannerjee, K. Aikat, Bioethanol production from agricultural wastes: An overview, Renew. Energy. 37 (2012) 19-27. doi:10.1016/j.renene.2011.06.045.

[6] J.M. Asko, H. Lauri, Process for making xylose, US Patent 4075406, 1975.

[7] D. Ballerini, F. Nativel, Procédé et unité de production en continu d'un mélange de sucres contenant au moins $80 \%$ de xylose à partir d'un substrat lignocellulosique, FR Patent 2655661 (B1), 1994.

[8] J.A. Ferreira, C.O. Teixeira, S.M. Soares, Process for the production of crystalline xylose from sugar cane bagasse, crystalline xylose obtained by said process, process for the production of xylitol from the said xylose and crystalline xylitol obtained thereby, WO Patent 108739 (A2), 2004.

[9] H. Heikkilä, K. Hyoky, Method for recovering xylose, US Patent 5084104, 1992.

[10] H. Heikkilä, J. Kuisma, M. Lindroos, O. Puuppo, Method of producing xylose, US Patent 6239274, 2001.

[11] H. Heikkilä, J. Lewandowski, M. Lindroos, P. Saari, Process of producing xylose and dissolving pulp, WO Patent 046532 (A1), 2010.

[12] K.-K. Cheng, J.-P.Ge, J.-A.Zhang, H.-Z.Ling, Y.-J.Zhou, M.-D.Yang, et al., Fermentation of pretreated sugarcane bagasse hemicellulose hydrolysate to ethanol by Pachysolentannophilus, Biotechnol.Lett. 29 (2007) 1051-1055. doi:10.1007/s10529-007-9361-2.

[13] P.V. Vyas, B.G. Shah, G.S. Trivedi, P.M. Gaur, P. Ray, S.K. Adhikary, Separation of inorganic and organic acids from glyoxal by electrodialysis, Desalination. 140 (2001) 47-54. doi:10.1016/S0011-9164(01)00353-8.

[14] J.-S. Park, J.-H.Song, K.-H.Yeon, S.-H. Moon, Removal of hardness ions from tap water using electromembrane processes, Desalination. 202 (2007) 1-8. doi:10.1016/j.desal.2005.12.031. process during the separation of lactic acid from a complex mixture, J. Membr. Sci. 249 (2005) 173-182. doi:10.1016/j.memsci.2004.08.033. 
[16] V. Thang, W. Koschuh, S. Novalin, Electrodialysis versus chromatography for desalting silage juice: Comparison of both processes with regard to energy consumption, J. Membr. Sci. (2005). doi:10.1016/j.memsci.2005.01.044.

[17] C. Huang, T. Xu, Y. Zhang, Y. Xue, G. Chen, Application of electrodialysis to the production of organic acids: State-of-the-art and recent developments, J. Membr. Sci. 288 (2007) 1-12. doi:10.1016/j.memsci.2006.11.026.

[18] C.-L. Blanc, M.-A. Theoleyre, F. Lutin, D. Pareau, M. Stambouli, Purification of organic acids by chromatography: Adsorption isotherms and impact of elution flow rate, Sep. Purif. Technol. 141 (2015) 105-112. doi:10.1016/j.seppur.2014.11.032.

[19] E.G. Lee, S.H. Kang, H.H. Kim, Y.K. Chang, Recovery of lactic acid from fermentation broth by the two-stage process of nanofiltration and water-splitting electrodialysis, Biotechnol. Bioprocess Eng. 11 (2006) 313-318. doi:10.1007/BF03026246.

[20] H.-J. Lee, S.J. Ahn, Y.-J.Seo, J.-W.Lee, A feasibility study on the multistage process for the oxalic acid pretreatment of a lignocellulosic biomass using electrodialysis, Bioresour. Technol. 130 (2013) 211-217. doi:10.1016/j.biortech.2012.12.061.

[21] S. Park, J.H. Lee, T. Kim, J. Kim, S. Kim, Method of producing xylitol using hydrolysate containing xylose and arabinose prepared from byproduct of tropical fruit biomass, WO Patent $096971(A 1), 2008$.

[22] J.H. Lee, J. An, S. Park, T. Kim, S. Kim, Economic process for producing xylose from hydrolysate using electrodialysis and direct recovery method, US Patent 0211366 (A1), 2012.

[23] G. Liu, Y. Liu, H. Shi, Y. Qian, Application of inorganic membranes in the alkali recovery process, Desalination 169 (2004) 193-205. doi:10.1016/j.biotechadv.2012.01.015. 